\title{
Vertical distribution of planktonic ciliates - an experimental analysis of swimming behaviour
}

\author{
Per R. Jonsson
}

Tjärnö Marine Biological Laboratory, Pl. 2781, S-452 00 Strömstad, Sweden

\begin{abstract}
Many marine planktonic ciliates accumulate close to the water surface or around the pycnocline. Similar vertical distribution patterns are repeated if natural or cultured populations are allowed to swim in an experimental water-column. Turbulence, light, pycnocline or chemical gradients do not seem to be necessary to explain the accumulation close to the surface. It is suggested that gravity is the ultimate cause for directed swimming towards the surface, although no evidence could be found for a statocyst-like mechanoreceptor. Experimental analysis of ciliate models in glycerol and manipulations of ciliate density as well as medium density indicate that the negative geotaxis results from interactions between sinking velocity, swimming velocity, tumbling rate and shape or density asymmetry of the cell. This is supported by the lability of the geotaxis which can be reversed by changing temperature or light intensity which correlate with changes in swimming patterns. Measurements of vertical velocities show that the ciliates studied can move between 1 and $2.5 \mathrm{~m} \mathrm{~h}^{-1}$ and this may determine, together with water turbulence, the vertical distribution of planktonic ciliates. A simple stochastic model was constructed in an attempt to study the combined effects of vertical swimming velocity and water turbulence. This model explains the different distribution patterns observed in the field as a function of the relative magnitude of vertical swimming velocity and water turbulence rate. The ecological significance of a possible ability of planktonic ciliates to influence their vertical distribution is discussed.
\end{abstract}

\section{INTRODUCTION}

The recognition of Protozod, such as heterotrophic flagellates and ciliates, as important predators on picoand nanoplankton in the marine pelagial (Spittler 1973, Heinbokel 1978, Capriulo 1982, Fenchel 1982, Rassoulzadegan 1982, Azam et al, 1983, Andersen \& Sørensen 1986, Jonsson 1986, Verity 1986, Sherr \& Sherr 1987) calls for more detailed studies of the functional biology of these groups of organisms. An interesting question with profound implications for plankton ecology is to what extent plankters are able to orient in response to environmental stimuli. The best known behaviour of plankters is the diurnal vertical migration of many mesozooplankters, with some of them migrating several $100 \mathrm{~m}$ (e.g. Marshall \& Orr 1955, Longhurst 1976). Phototaxic behaviour of many autotrophs is also well established although the ecological significance of such behaviour is mostly unknown. Natural populations of dinoflagellates show diurnal changes in their vertical distribution (Hasle 1950, Eppley et al. 1968), and experimental studies (Eppley et al. 1968, Heany \& Eppley 1981) indicate that this is caused by phototaxis, modulated by physiological status. Microscale behaviour of bacteria has also been suggested (Azam \& Ammerman 1984); motile bacteria may accumulate around algal cells through a chemokinetical response to exudate gradients. In lakes, chemokinetic and photokinetic responses have been shown to influence the vertical distributions in some ciliates (Finlay et al. 1987). In loxodid ciliates a mechanoreceptor based geotaxis has been demonstrated (Fenchel \& Finlay 1984, 1986).

Marine planktonic ciliates mainly feed on nanosized prey (Rassoulzadegan \& Etienne 1981, Capriulo 1982, Jonsson 1986, Verity 1986) including many autotrophic flagellates. In neritic areas, primary production is confined to a thin surface layer, and prey availability for ciliates decreases with depth with a marked reduction below the pycnocline. Because ciliates are denser than seawater, they face the risk of sinking out of the surface layer. An interesting possibility is that planktonic ciliates, through directed motility, may compensate for sinking and even move towards the prey-rich surface waters. Some previous studies support this possibility: planktonic ciliates 
have been found most concentrated near the water surface (Gillbricht 1955, Vitiello 1964, Beers \& Stewart 1969, Middlebrook et al. 1987). However, no study has specifically dealt with the possible mechanisms by which non-random distributions of planktonic ciliates are maintained in the sea. Here I report a detailed study of vertical distributions of marine planktonic ciliates and an analysis of swimming behaviour designed to investigate the possibility that many planktonic ciliates can influence their vertical position in the water-column.

\section{MATERIALS AND METHODS}

Material. Both cultured and natural populations of planktonic ciliates were used. Strombidium reticulatum (Leegaard), Lohmanniella oviformis Leegaard and Tintinnopsis campanula (Ehrenberg) were isolated from the Kosterfjord, Sweden, and cultured as described in Jonsson (1986).

Field vertical profiles. The sampling site was located near the shores ( $9 \mathrm{~m}$ water depth) of the Kosterfjord on the west coast of Sweden. This area is influenced by brackish water coming from the Baltic and flowing north along the coast. Occasionally freshwater from the Norwegian river Glomma may also affect the Kosterfjord. This results in great variations in salinity of the surface water, which varies between 16 and 31 ppt. Normally, a pronounced halocline is present at 2 to $10 \mathrm{~m}$ depth with salinity approaching 31 to $33 \mathrm{ppt}$ below $40 \mathrm{~m}$. With a hand-worked pump (Nalgene) and a $5 \mathrm{~m}$ hose samples were taken at $0.2 \mathrm{~m}$ intervals from the surface down to $2 \mathrm{~m}$ depth, and at $0.4 \mathrm{~m}$ intervals between 2 to $5 \mathrm{~m}$ depth. All samplings were made around mid-day. Samples, 50 or $100 \mathrm{ml}$, were fixed with acid Lugol's and centrifuged (1000 $\times$ g, $15 \mathrm{~min})$. Centrifuged plankton was transferred to $3 \mathrm{ml}$ sedimentation counting chambers, and ciliates were identified and counted using an inverted microscope (Nikon Diavert, 100 to $200 \times$ ). Identification was sometimes facilitated by observations of living ciliates. The taxonomy of naked oligotrich ciliates (suborder Oligotrichina) is largely based on insufficient descriptions and the names used here may be regarded as provisional following Leegaard (1915). Identification of tintinnids (suborder Tintinnina) was based on the lorica descriptions of Marshall (1969). This also poses some problems, particularly for species agglutinating foreign particles to the lorica, because of lorica polymorphism (Bakker \& Phaff 1976, Laval-Peuto \& Brownlee 1986). On each sampling occasion temperature and salinity profiles were recorded using a YSI-33 salinometer From these profiles, density profiles were calculated according to Cox et al. (1970).
Experimental vertical profiles. Vertical distribution of planktonic ciliates, either cultured or natural populations, was studied in wide $100 \mathrm{ml}$ test tubes $(200 \times$ $25 \mathrm{~mm}$ ). At least 2 replicates of the test tubes were filled with ciliates and incubated in the dark. To reduce convection currents within the tubes these were kept in a stirred water bath. All experiments were performed during the day. The vertical distribution of a population was monitored by taking samples $(0.2$ to $3 \mathrm{ml}$, depending on ciliate concentration) at 4 or 5 depths from the surface to the bottom of the tubes (150 $\mathrm{mm}$ depth). Ciliates were then fixed with Lugol's and counted in sedimentation chambers on an inverted microscope. In separate experiments the effects of changes in light intensity and temperature on vertical distribution were studied.

In order to test if a pycnocline can prevent planktonic ciliates from moving downwards, an experiment with an artificial halocline was designed. Natural seawater containing ciliates was collected from the surface, and some of the water was filtered through a GF/C filter. The filtered seawater from the surface was mixed with filtered seawater from $40 \mathrm{~m}$ depth which had a higher salinity (33 ppt). This yielded a salinity approximately $4 \mathrm{ppt}$ above that of the original surface water. Test tubes $(100 \mathrm{ml})$ were filled to a depth of $100 \mathrm{~mm}$ with unfiltered surface water, and then the filtered, more saline seawater, was gently introduced at the bottom. This artificial halocline was about 5 times steeper than the most extreme gradients which I have observed in the field. As a control, filtered surface water (without increased salinity), but slightly cooled to reduce mixing, was introduced at the bottom. After $1 \mathrm{~h}$, samples $(3 \mathrm{ml})$ were collected from 5 depths from surface to the bottom (150 mm depth). Samples were fixed with Lugol's, and ciliates were counted in sedimentation chambers. At the termination of the experiment, salinity at the 5 sampling depths was measured to check that the halocline had remained intact.

Measurements of vertical velocity. Vertical velocity of ciliates was measured using 2 different methods. Velocities of Laboea strobila, Parafavella denticulata and Tintinnopsis campanula were measured as averages for individual ciliates swimming in a vertical column. In Strombidium reticulatum, S. cf. emergens and Lohmanniella oviformis the upward drift of an initially homogeneously suspended population was measured. This was done by counting ciliates moving upwards and downwards as a function of time at the top of a $115 \mathrm{~mm}$ vertical water-column. The cumulative net migration was plotted against time, and reached an equilibrium level when steady-state was achieved and the net migration was zero. Division of the depth of the column with time indicated by extrapolation of the initial linear part of the curve to the equilibrium level is 
the mean vertical drift of the population (Fenchel \& Finlay 1984).

Swimming patterns. In connection with the studies of vertical distribution in experimental columns, swimming patterns were recorded with a video camera (Panasonic camera WVP-100E and NV-180 taperecorder) fitted to a horizontally mounted dissecting microscope (Wild M5, 12 to 25×). Sequences were played frame by frame $\left(25 \mathrm{~s}^{-1}\right)$, and the position of individual ciliates was plotted on plastic sheets attached to the screen. Swimming velocities and tumbling rates were quantified from these tracings.

Test of chemosensory responses. To test if the vertical distribution of planktonic ciliates was affected by prey density, presumably through chemosensory responses, behaviour in prey gradients was studied. Vertical prey gradients were created by filling $50 \mathrm{ml}$ test tubes $(200 \times$ $18 \mathrm{~mm}$ ) to a height of $30 \mathrm{~mm}$ with a suspension of the autotrophic flagellate, Pyramimonas sp. (ca $10^{5}$ cells $\mathrm{ml}^{-1}$ ), and then adding filtered and autoclaved seawater up to $150 \mathrm{~mm}$ height. To reduce mixing, the salinity of the filtered top water was reduced by 3 ppt and the test tubes were placed in a stirred water bath. Cultured Strombidium reticulatum were then introduced into the prey suspension at the bottom. After $1 \mathrm{~h}$, samples $(2 \mathrm{ml})$ were taken at 5 depths. Similar experiments in test tubes containing filtered and autoclaved seawater, with and without salinity stratification, served as controls. Because it may be difficult to distinguish between chemical and mechanical responses of a predator, a simpler experiment was also performed. Small capillary tubes $(10 \times 0.5 \mathrm{~mm})$ were filled with centrifuged flagellates (Pyramimonas sp.) or bacteria (Pseudomonas sp.) and placed in culture dishes containing filtered and autoclaved seawater. Cultured $S$. reticulatum and $S$. vestitum were then added to the culture dishes. Accumulation or behavioural change in the ciliates around the capillary tubes were monitored with a dissecting microscope.

Sinking and reorientation rates. Sinking rates of $\mathrm{OsO}_{4}$-fixed ( $\left.2 \% \mathrm{w} / \mathrm{v}\right)$ Strombidium reticulatum, Strombidium sp., Tintinnopsis campanula and $T$. parvula were measured in spectrophotometer cells in stirred water-baths. The sinking of individual ciliates was followed with a horizontally mounted dissecting microscope. When fixed individuals of $S$. reticulatum and Strombidium sp. sink, they reorient so that the cells are aligned along the vertical axis with the membranelle zone upwards. To measure this reorientation rate, ciliates were studied in a spectrophotometer cell as described above. The water with fixed ciliates was stirred for a few seconds making orientation of ciliates more or less random. When stirring ceased, the time to reorient from 135 to $45^{\circ}\left(0^{\circ}\right.$ when membranelle zone is upward) was measured. For Lohmanniella oviformis, reorientation rate was measured on living cells. This was possible because this ciliate hovers while feeding. At regular intervals (a few seconds), this hovering is interrupted by swift jumps (about $3000 \mu \mathrm{m} \mathrm{s}^{-1}$ ). During the hovering phase, ciliates could be seen to reorient until the membranelle zone was pointing upwards and the rate of change was measured.

Models in glycerol. To study the effect of density and drag asymmetry on reorientation of a body sinking in a viscous fluid, experiments with scale-models sinking in glycerol were performed. The models were shaped as ellipsoids slightly pointed at one end, $3 \mathrm{~mm}$ in cross section and made of rubber with a density of $1.31 \mathrm{~g} \mathrm{~cm}^{-3}$. Reynolds number of the sinking models were ca $10^{-3}$ and should appropriately scale sinking ciliates with viscous force predominating. The effect of a density asymmetry was studied by gluing small pieces of plasticine (density $1.91 \mathrm{~g} \mathrm{~cm}^{-3}$ ) of varying size on the models. The plasticine pieces were flattened out on the pointed end to reduce changes in the shape of the model. A possible drag asymmetry due to the membranelle zone was simulated using varying numbers of small pieces of plastic film fixed like membranelles on the blunt end of the model. Sinking models were video recorded using a macro-lens, and reorientation was followed frame by frame as described above for swimming ciliates.

Manipulation of ciliate and medium density. Density of Tintinnopsis campanula and medium were manipulated in order to determine if the density of the lorica of tintinnids affects vertical swimming. In nature, $T$. campanula agglutinate foreign particles, such as mineral grains and diatom frustules to its lorica. This ability was utilized to change the density of the lorica. Latex beads $(5.8 \mu \mathrm{m})$ were added to the culture medium, and newly divided tintinnids were allowed to build their loricae with these beads. Latex beads have a density of $1.025 \mathrm{~g} \mathrm{~cm}^{-3}$ which is close to that of seawater, thus making the lorica lighter than natural Ioricae which contain mineral grains. Tintinnids with the 2 kinds of loricae were allowed to swim upward from the bottom of a culture dish. The time taken to swim from the bottom to the surface was measured. Vertical velocity was first measured for tintinnids swimming in filtered seawater, then the same individuals were transferred to a medium made of a mixture of seawater and deuteriumoxide (heavy water) with a density of $1.052 \mathrm{~g} \mathrm{~cm}^{-3}$. The mixture was prepared by mixing deuteriumoxide and partly evaporated (40 ppt) seawater to yield seawater of 25 ppt containing about $35 \%$ deuteriumoxide.

Computer simulation. A simple model was constructed to simulate the vertical distribution of planktonic ciliates as a function of vertical swimming velocity and turbulent diffusion. The model assumes that turbulence 


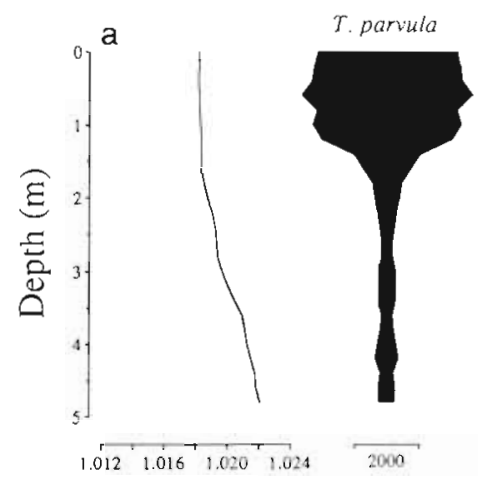

Density $\left(\mathrm{g} \mathrm{cm}^{-3}\right)$

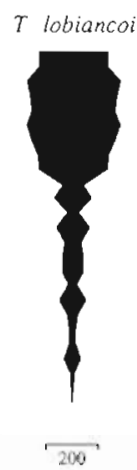

200

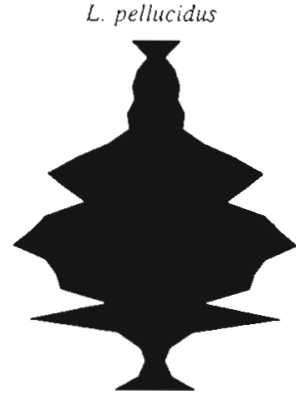

200

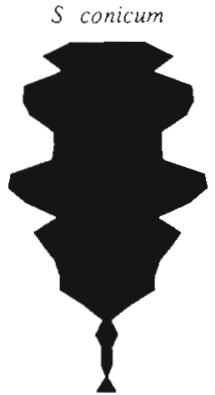

S. vertum

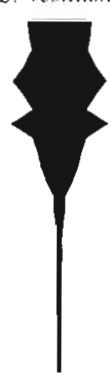

2000

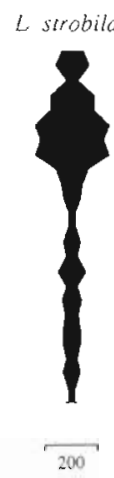

$\sqrt{2000}$
200

Abundance (cells $\mathrm{l}^{-1}$ )

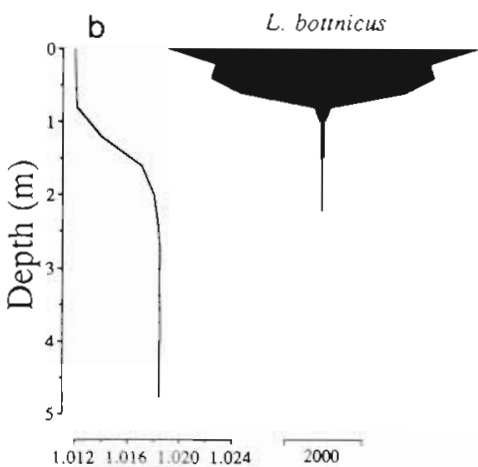

Density $\left(\mathrm{g} \mathrm{cm}^{-3}\right)$

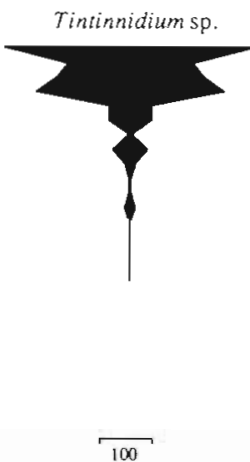

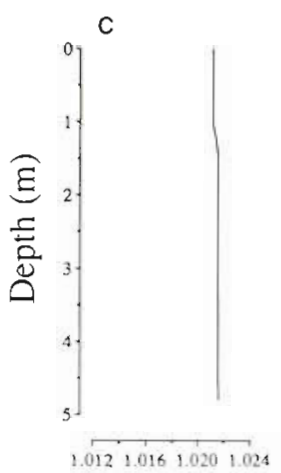

Density $\left(\mathrm{g} \mathrm{cm}^{-3}\right)$

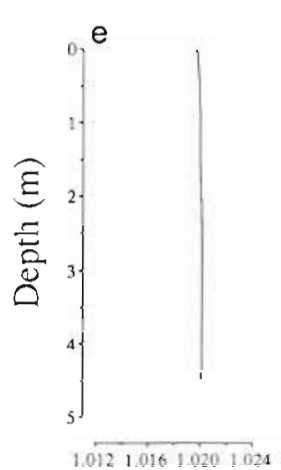

Density $\left(\mathrm{g} \mathrm{cm}^{-3}\right)$

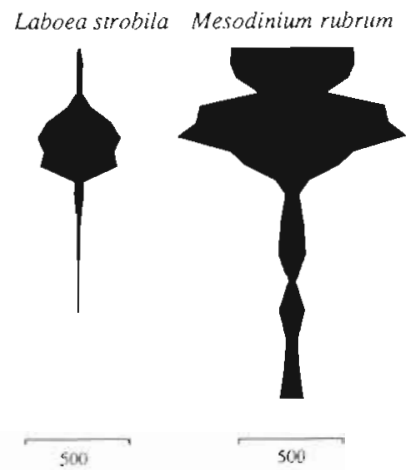

Abundance (cells $\mathrm{l}^{-1}$ )
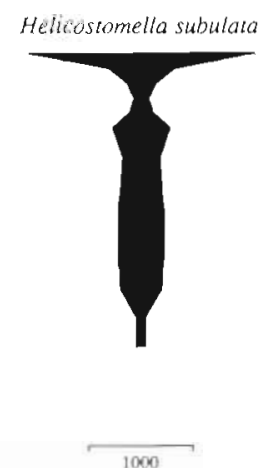

Abundance (cells $\mathrm{H}^{-1}$ )
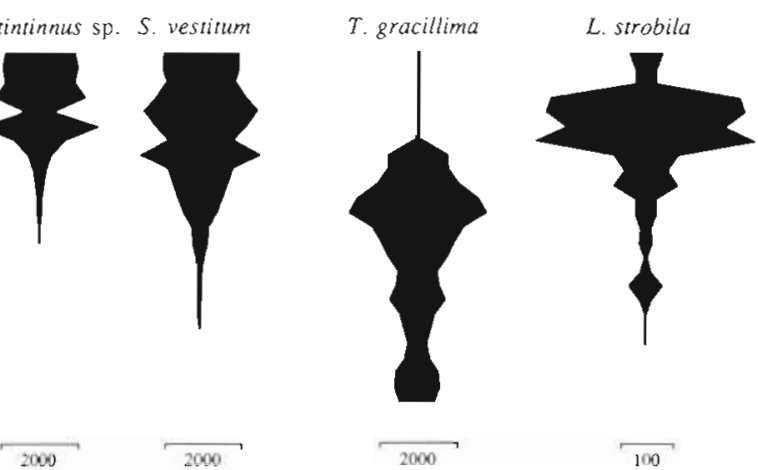

2000

$\underset{2000}{\longrightarrow}$

$\longdiv { 1 0 0 }$

Abundance (cells ${ }^{-1}$ )

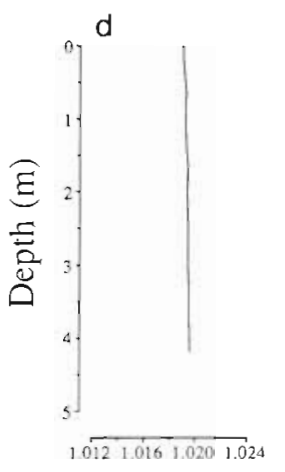

Density $\left(\mathrm{g} \mathrm{cm}^{-3}\right)$

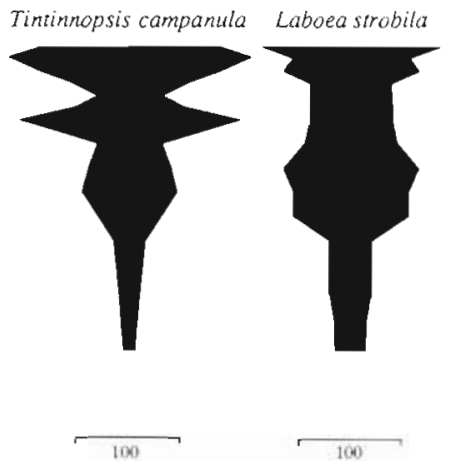

Abundance (cells $\mathrm{l}^{-1}$ )

Fig. 1 Vertical distribution of planktonic ciliates and density profiles on 5 sampling occasions in 1987 (around midday on

(a) 6 May; (b) 3 Jul; (c) 4 Oct; (d) 19 Oct; (e) 12 Oct] 


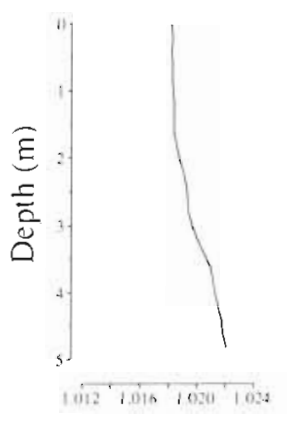

Density $\left(\mathrm{g} \mathrm{cm}^{-3}\right)$
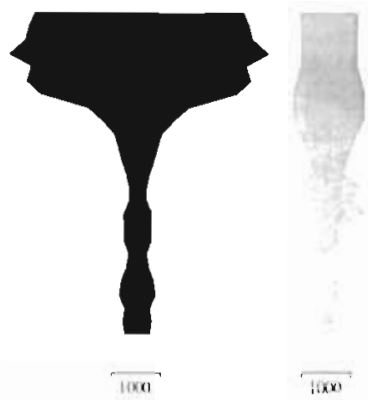

Abundance (cells or loricae $\mathrm{l}^{-1}$ )
Fig. 2. Tintinnopsis parvula. Vertical distribution at midday on May 6, 1987 of living cells (black) and empty loricae (stippled)

rate decays exponentially downwards and is reduced to $10 \%$ at the pycnocline depth. Turbulence is simulated as a 1-dimensional random walk given by $K=U^{2} T / 2$, where $\mathrm{K}=$ turbulence rate; $\mathrm{U}=\mathrm{up}$ - or downward velocity of water; $\mathrm{T}=$ time between changes of direction (Fenchel \& Finlay 1984).

\section{RESULTS}

\section{Field vertical profiles}

Vertical distribution of some natural populations of planktonic ciliates from 5 sampling occasions are shown in Fig. 1. Depth and development of the pycnocline varied considerably between sampling dates as shown by the density profiles mainly as a result of variations in surface water salinity. It is obvious that most ciliate species show a pronounced non-random distribution and the most striking feature is the accumulation close to the surface or around the pycnocline. Many species have a bimodal distribution with local maxima close to the surface and around the pycnocline, and for most of the observed ciliates the abundance drops suddenly below the pycnocline. There is some variation between the species. Tontonia gracillima, Strombidium conicum and Leprotintinnus pellucidus have a weaker tendency to accumulate close to the surface than tintinnids like $L$. bottnicus, Tintinnidium sp., Tintinnopsis parvula, $T$. campanula and Helicostomella subulata. In Fig. 2 the vertical distribution of living $T$, parvula and empty loricae are compared. The distribution of empty loricae clearly differs from that of the living cells and the relative abundance of empty loricae increases with depth.

\section{Experimental vertical profiles}

When cultures of Strombidium reticulatum, Lohmanniella oviformis and natural populations of $S$. vestitum, $S$. cf. emergens, Helicostomella subulata and Tintin- nopsis campanula are allowed to swim in a $100 \mathrm{ml}$ test tube set in a water-bath, members of all species accumulate close to the surface (Fig. 3). Experiments were carried out in darkness and in the absence of turbulence since heat convection was negligible. No obvious gradients of food particles were observed. Observations of swimming ciliates reveal that the nonrandom vertical distribution is caused by net upward swimming. The average upward velocity component ranges from 260 to $690 \mu \mathrm{m} \mathrm{s}^{-1}$ (Table 1 ) which is more than half of the swimming speed of the studied species, thus indicating high directionality.

The distribution of dividing Strombidium reticulatum differs drastically from that of non-dividing cells and is heavily skewed towards the bottom (Fig. 4). Oligotrich ciliates have apokinetal stomatogenesis, causing the newly developed membranelle zone to point in the opposite direction to the parental membranelles. This disrupts normal swimming behaviour and causes a reduced swimming velocity, an increased sinking velocity and peculiar swimming paths. These changes of swimming behaviour probably cause dividing cells to accumulate at the bottom.

\section{Effects of light and temperature}

The lability of the surface-skewed distribution was demonstrated by changing light intensity or temperature. In Fig. 5 accumulation towards the surface of Strombidium reticulatum is reversed when light intensity suddenly drops. The change in vertical distribution is accompanied by a reduction in swimming velocity and time between tumbles (Fig. 6). The changes in vertical distribution and swimming pattern are mainly temporary. After $1 \mathrm{~h}$, swimming speed increases but remains somewhat lower than in the light, and the ciliates once more accumulate at the surface. A similar pattern is found if temperature is lowered. A reduction

Table 1. Vertical velocity of some planktonic ciliates, either directly measured on individual ciliates (mean $\pm \mathrm{SE}$ ) (I\}) or based on the time taken for a population to reach a steadystate vertical distribution (S). See text for further information

\begin{tabular}{|lcl|}
\hline Species & Method & $\begin{array}{c}\text { Vertical velocity } \\
\left(\mu \mathrm{m} \mathrm{s}^{-1}\right)\end{array}$ \\
\hline Laboea strobia & I & $430 \pm 170(13)^{\circ}$ \\
Parafavella denticulata & I & $690 \pm 220(3)$ \\
Tintinnopsis campanula & I & $260 \pm 42(7)$ \\
Lohmanniella oviformis & S & 340 \\
Strombidium cf. emergens & S & 680 \\
Strombidium reticulatum & S & 450 \\
- Sample size & & \\
& & \\
\hline
\end{tabular}



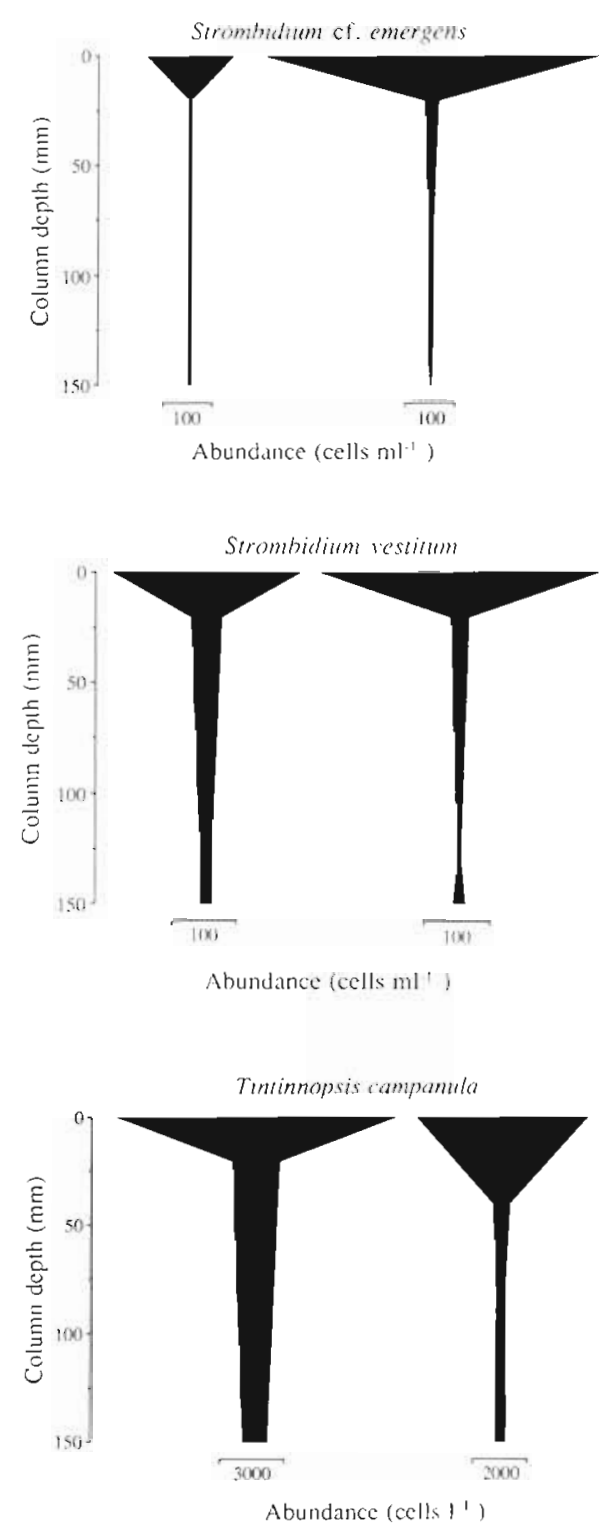

in temperature from 18 to $4{ }^{\circ} \mathrm{C}$ strongly affects the distributions of $S$. reticulatum and $S$. cf. emergens as shown in Fig. 7, and drastically reduces swimming speed of $S$. reticulatum (Table 2 ).

\section{Halocline effects}

Although a pycnocline is not a necessary condition for the observed accumulations of ciliates in the experimental water-columns, I tested if a pycnocline has any effect on the vertical distribution. The aim was to test if an artificial halocline prevented ciliates from entering the more saline bottom water. The results in Fig. 8 show some scatter but no essential difference can be seen between the halocline columns and the controls. Further evidence that a steep halocline does not affect
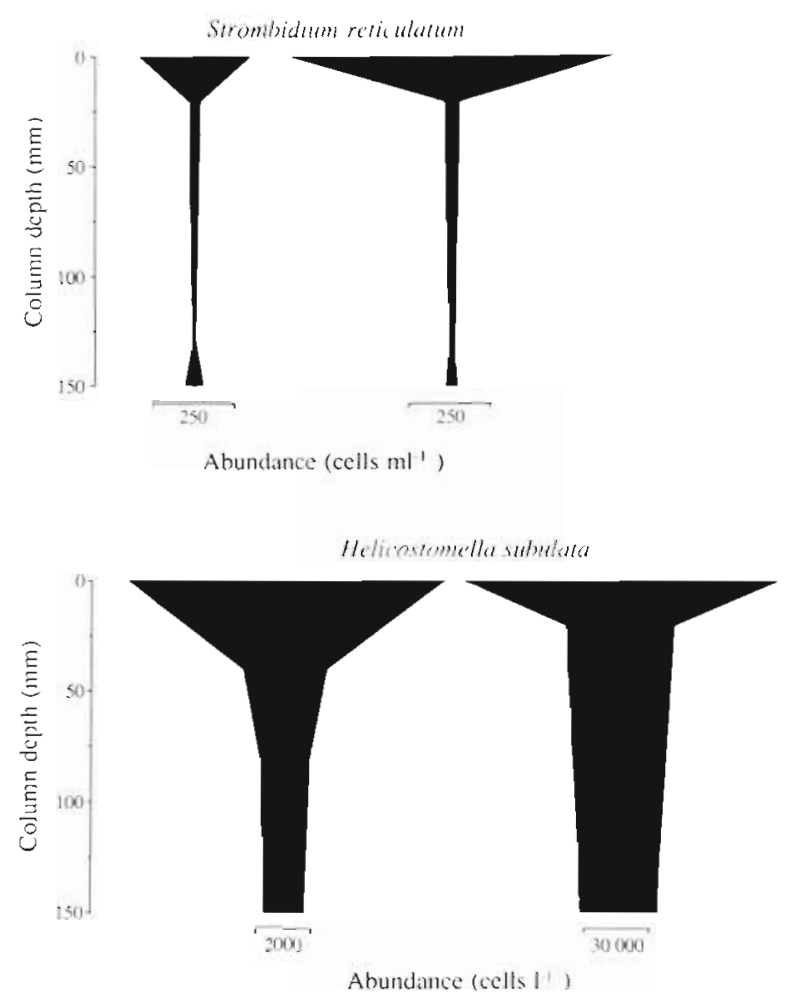

Fig. 3. Vertical distribution of 5 species of planktonic ciliates in experimental water-columns

ciliate behaviour is seen in Fig. 9; Strombidium reticulatum accumulated at the surface irrespective of the presence or absence of a halocline. Observations of individual S. reticulatum and Tintinnopsis campanula starting from the bottom of a test tube and swimming through a steep halocline (ca $0.5 \mathrm{ppt} \mathrm{cm}^{-1}$ ) reveal no changes in upward swimming behaviour.

\section{Chemosensory ability}

Experiments show that even an extremely steep prey gradient, decreasing towards the surface, has no significant effect on the vertical distribution of Strombidium reticulatum (Fig. 9). Absence of responses to food density is also evident when $S$. reticulatum or $S$. vestitum swim through food patches, made with capil- 


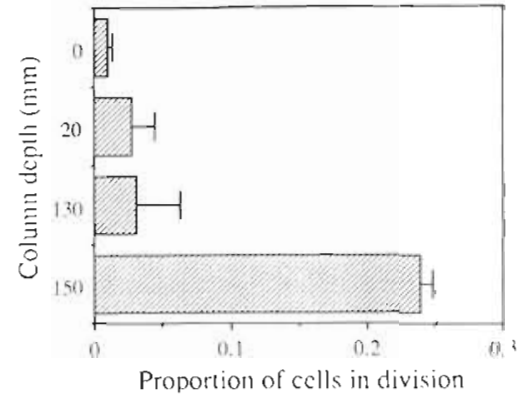

Fig. 4. Strombidium reticulatum. Proportion (mean $\pm S E$ ) of dividing cells as a function of column depth

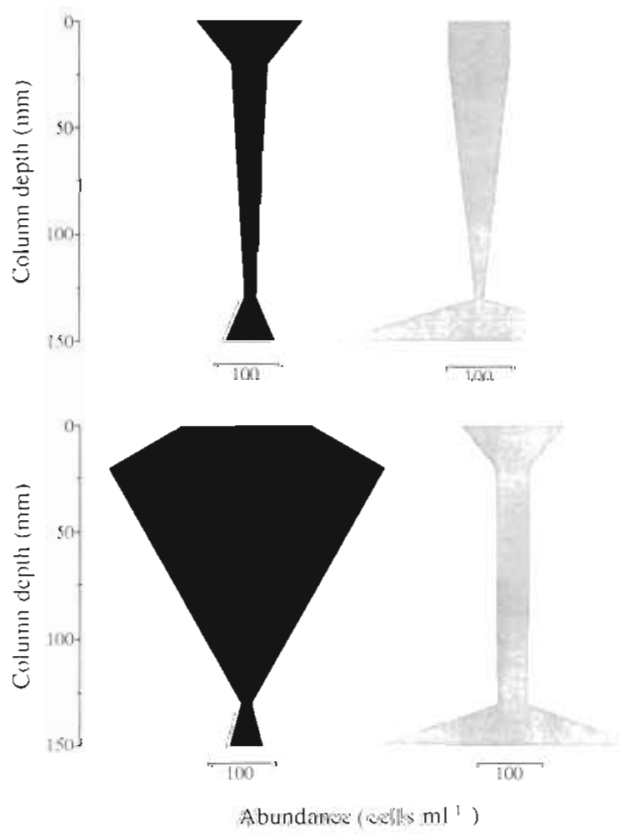

Fig. 5. Strombidium reticulatum. Vertical distribution (2 replicates) in light (black) and 15 min after sudden drop in light intensity (stippled)
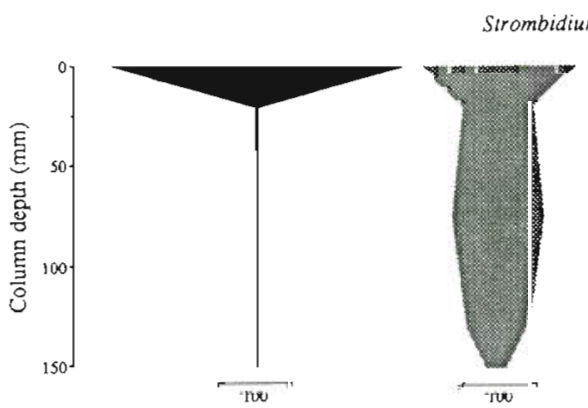

trombidium cf. emergens

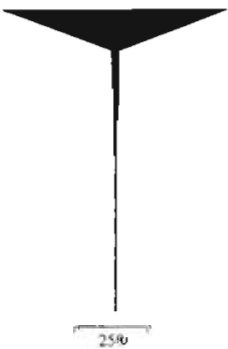

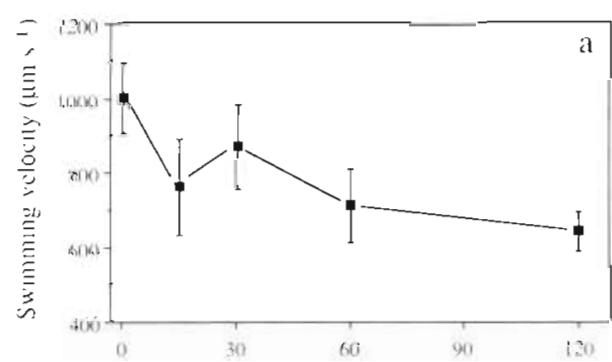

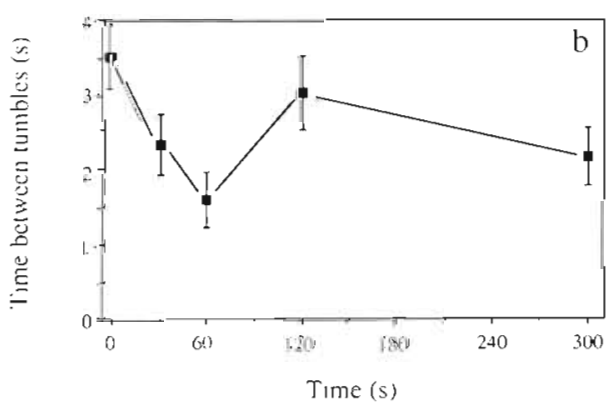

Fig. 6. Strombidium reticulatum. Changes in swimming velocity (a) and time between tumbles (b) (mean \pm SE) following sudden drop in light intensity

lary tubes slowly leaking microalgae and bacteria. When these ciliates approach or swim through a food patch they change neither swimming velocity nor tumbling rate and their distributions remain random relative to the food patches.

\section{Hydrodynamical reorientation}

When fixed oligotrich ciliates are allowed to $\sin k$ through the water, the cells start to reorient until the anterior end points upwards. As seen in Table 3 , this reorientation of the cells is very fast, 10 to $30^{\circ} \mathrm{s}^{-1}$, in fact so fast that it was difficult to measure. Unfortunately, I could not obtain any meaningful measurements of reorientation rate of tintinnids because all species tested contract into the lorica on fixation. Since the observed reorientation of oligotrich ciliates may be a

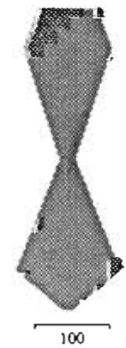

Strombidium reficulalum

Abundance (cclls $\mathrm{ml}^{1}$ )

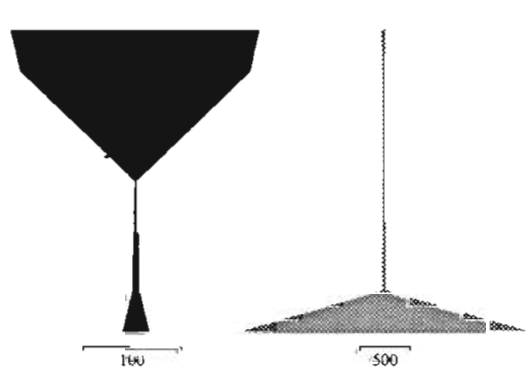

Fig. 7. Vertical distribution of Strombidium cf. emergens ( 2 replicates) and S. reticulatum in $18^{\circ} \mathrm{C}$ (black) and in $4^{\circ} \mathrm{C}$ (stippled) 
Table 2. Strombidium reticulatum. Swimming velocity $( \pm \mathrm{SE})$ as a function of temperature

\begin{tabular}{|cc|}
\hline Temperature $\left({ }^{\circ} \mathrm{C}\right)$ & Swimming velocity $\left(\mathrm{um} \mathrm{s}^{-1}\right)$ \\
\hline 18.5 & $1070 \pm 73(14)^{\circ}$ \\
4 & $410 \pm 28(14)$ \\
- Sample size & \\
\hline
\end{tabular}
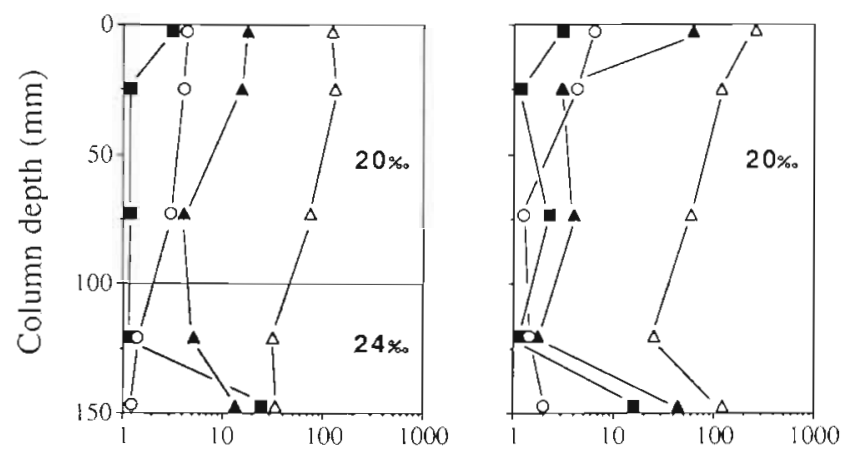

Abundance (cells $\mathrm{ml}^{-1}$ )

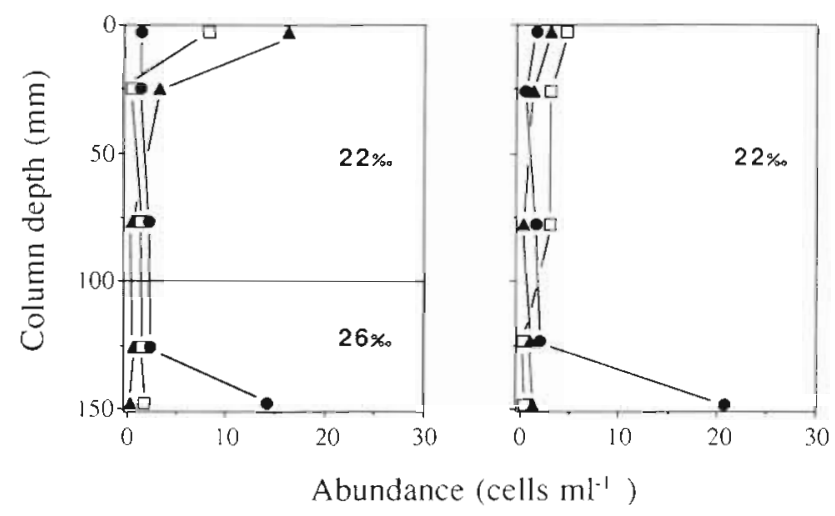

Fig. 8. Vertical distribution of planktonic ciliates in columns with and without artificial halocline (2 replicates). (\$) Strombidium conicum; (4) S. cf. emergens; (ㅁ) Tontonia gracillima; (-) Helicostomella subulata; (o) Tintinnopsis campanula; (•) Favella ehrenbergii

possible mechanism for ciliates to swim upwards with greater probability than downwards, an attempt was made to analyze the causes of reorientation. Scalemodels of ciliates were allowed to sink in a column of glycerol where viscosity and dimensions of the models were chosen to simulate a hydrodynamical situation where viscous forces predominate. When an ellipsoid model is dropped in the glycerol column, it starts to sink, but keeps its initial orientation. In the first series of experiments, the density distribution of a model was manipulated with small weights at the posterior end. Fig. 10a illustrates increases in reorientation rate with density asymmetry; without density asymmetry

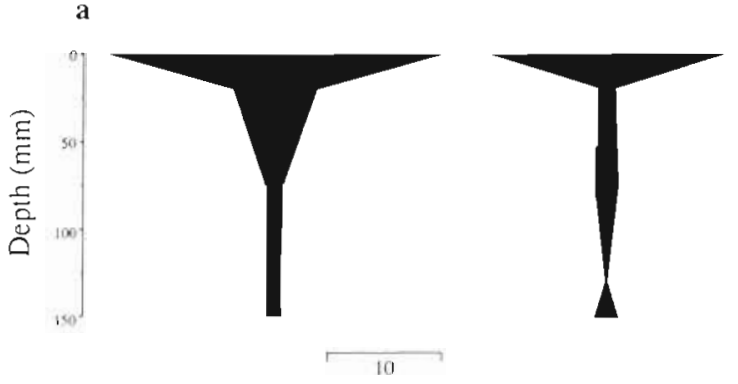

Abundance (cells $\mathrm{ml}^{\prime}$ )

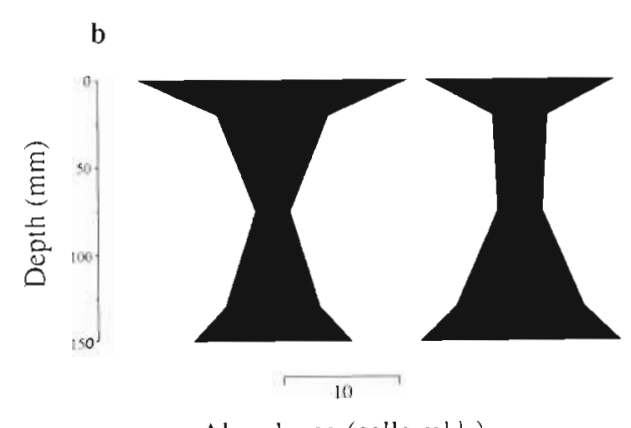

Abundance (cells $\mathrm{ml} \mathrm{l}^{\prime}$ )
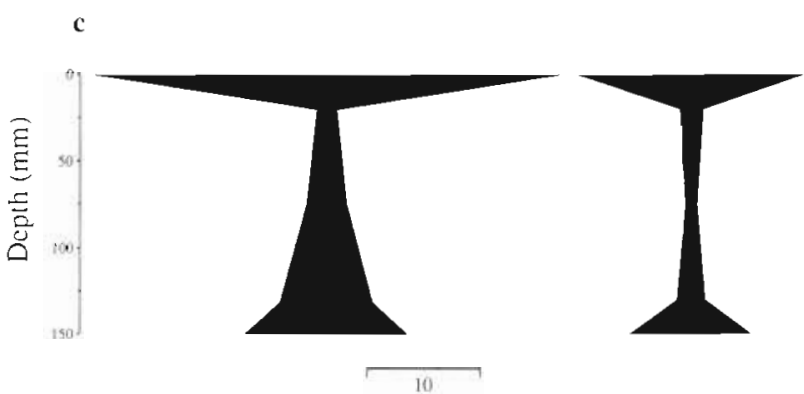

Abundance (cells ml')

Fig. 9. Strombidium reticulatum. Effect of prey gradient on vertical distribution. (a) Prey gradient decreasing towards surface in a salinity-stratified column; (b) without prey in a salinity-stratified column; (c) without prey in a mixed column

Table 3. Sinking rates $( \pm S E$ ) and reorientation rates ( $\pm S E$ ) of some planktonic ciliates. Results are for $\mathrm{OsO}_{4}$-fixed cells, except for Lohmanniella oviformis where measurements were made on living cells

\begin{tabular}{|lcc|}
\hline Species & $\begin{array}{c}\text { Sinking } \\
\text { rate }\left(\mu \mathrm{m} \mathrm{s} \mathrm{s}^{-1}\right)\end{array}$ & $\begin{array}{c}\text { Reorientation } \\
\text { rate }\left(\mathrm{s}^{-1}\right)\end{array}$ \\
\hline Strombidium reticulatum & $29 \pm 2.5(19)$ & $33 \pm 2.9(15)$ \\
Strombidium sp. & $29 \pm 2(26)$ & $22 \pm 2(24)$ \\
Lohmanniella oviformis & $\mathrm{nd} \cdot{ }^{\cdot}$ & $9.3 \pm 0.7(20)$ \\
Tintinnopsis parvula & $72 \pm 9(6)$ & nd \\
Tintinnopsis lobiancoi & $104 \pm 5.9(2)$ & nd \\
Empty loricae of & $66 \pm 4.1(4)$ & nd \\
& & \\
T lobiancoi & & \\
& & \\
- Sample size & & \\
Not determined & & \\
\end{tabular}




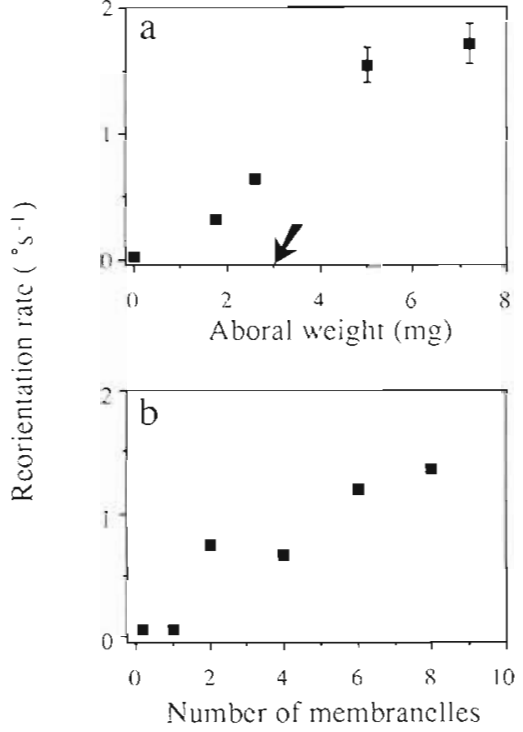

Fig. 10. Reorientation rate of scale models sinking in glycerol as a function of (a) aboral weight and (b) membranelle number. Arrow indicates the approximate scaled density asymmetry in Strombidium species

(weight $=0$ ) reorientation rate is 0 . Planktonic ciliates of the family Strombidiidae have cortical polysaccharide plates which cover the posterior end. Since polysaccharide is denser than cell contents, the cell should show some density asymmetry. This was roughly calculated assuming a density of the 1 um thick polysaccharide plates of $1.5 \mathrm{~g} \mathrm{~cm}^{-3}$ and a cell density of $1.07 \mathrm{~g} \mathrm{~cm}^{-3}$. The density asymmetry of the scale-model corresponding to the calculated asymmetry of the ciliate is shown with an arrow in Fig. 10a. In the second series of experiments I investigated the effect of shape asymmetry on reorientation rate. The most asymmetrical feature of oligotrich ciliates is the oral zone of membranelles. Individual membranelles were imitated by small pieces of plastic film which were fixed to the anterior part of the model. Reorientation rate as a function of the number of plastic 'membranelles' is shown in Fig. 10b. Without 'membranelles' reorientation rate is zero; it increases with the number of 'membranelles'. Note that reorientation rates of scale-models can only be used qualitatively since sinking rates measured as cell lengths per unit time did not scale.

\section{Tintinnid density asymmetry}

It is tempting to suggest that the lorica of tintinnids is denser than the cell and would cause reorientation of tintinnids resulting in a greater probability to swim upwards. To test this hypothesis an experiment was designed where density of both a tintinnid, Tintinnopsis campanula, and the medium were manipulated. By allowing tintinnids to build their lorica with latex beads the lorica became less dense as apparent from the reduction in sinking velocity shown in Table 4. The vertical velocity of the two kinds of tintinnids was first measured in seawater with normal density and then they were transferred to seawater with increased density by mixing seawater and deuteriumoxide (heavy water). As a control of any physiological changes caused by deuteriumoxide the ciliates were finally transferred back to seawater again and the vertical velocity was measured immediately. The results (Table 4) show that there is a statistical difference $(p<0.001)$ in vertical velocity between both the kinds of loricae and between the media, and the vertical velocities correlate positively with increased density asymmetry. The vertical velocities measured in seawater before and after transfer to the deuteriumoxide-containing medium are not significantly different $(p>0.05)$ although there is a trend of increasing velocity in the last treatment.

\section{DISCUSSION}

Previous works show that natural populations of marine planktonic ciliates often exhibit non-random

Table 4. Tintinnopsis campanula. Vertical velocity ( $\pm \mathrm{SE}$ ) and sinking velocity ( $\pm \mathrm{SE}$ ) as a function of ciliate and medium density. Density of ciliates was manipulated by letting tintinnids incorporate latex beads instead of mineral particles in their lorica; medium density was changed by mixing seawater with deuteriumoxide. Control of vertical velocity in sea-water was made after treatment with medium containing deuteriumoxide

\begin{tabular}{lccccc}
\hline Type of lorica & \multicolumn{2}{c}{$\rho=1.021 \mathrm{~g} \mathrm{~cm}^{-3}$} & $\begin{array}{c}\rho=1.052 \mathrm{~g} \mathrm{~cm}^{-3} \\
\text { Velocity } \\
\text { Vertical velocity }\end{array}$ & $\begin{array}{c}\text { Sinking velocity } \\
\text { Vertical velocity }\end{array}$ & $\begin{array}{c}\text { Control: } \rho=1.021 \mathrm{~g} \mathrm{~cm} \\
\text { Vertical velocity }\end{array}$ \\
\hline $\begin{array}{l}\text { Mineral particles } \\
\text { Latex beads }\end{array}$ & $122 \pm 16(6)^{\circ}$ & $260 \pm 42(7)$ & $87 \pm 6.9(6)$ & $160 \pm 29(7)$ & $310 \pm 38(7)$ \\
- Sample size & $67 \pm 5.2(7)$ & $64 \pm 19(11)$ & $44 \pm 2.5(4)$ & $34 \pm 5.2(11)$ & $140 \pm 61(9)$ \\
$p<0.001$ for vertical velocity between lorica types and between medium densities (2-way ANOVA) \\
$p>0.05$ for vertical velocity between seawater medium before and after treatment with deuteriumoxide (Mann-Whitney)
\end{tabular}


vertical distributions (Gillbricht 1955, Vitiello 1964, Beers \& Stewart 1969, Middlebrook et al. 1987). Generally the distributions are skewed towards the water surface, particularly for many tintinnids. Similar distribution patterns are found in the present study, and detailed sampling reveals that distributions differ between species of planktonic ciliates. Considering reproduction, mortality, stratification of water, wave and wind driven turbulence, a random vertical distribution can hardly be expected. But in addition to these non-adaptive processes, there is the interesting possibility that ciliates may, by directed motility, influence their vertical distribution. The strongest indication from the field profiles that ciliate motility may influence vertical distribution is the difference in distribution between tintinnids and their empty loricae (Fig. 2). The empty loricae show a distribution more skewed to the bottom than living tintinnids, although living tintinnids have greater sinking velocity than empty loricae (Table 3). However, it is difficult to conclude from mere field studies which mechanisms are causing the observed vertical distributions and to evaluate the contribution of ciliate swimming behaviour

To study individual mechanisms, vertical distributions of planktonic ciliates were studied in experimental water-columns. These show that the accumulation at the surface is not dependent on light, stratified water or turbulence. Haloclines many times steeper than found in the field do not significantly affect vertical distribution and ciliates swimming through steep haloclines do not exhibit changes in tumbling behaviour or obvious changes in swimming velocity. I therefore hypothesize that the observed accumulation around the pycnocline in the field is not caused by behavioural responses to the salinity and temperature gradient but rather is a result of reduced turbulence, as discussed below.

Absence of behavioural responses to patches of concentrated bacteria and algae indicates that chemical gradients are of minor importance as a cause of the oriented responses of the ciliates I studied. It is striking to compare the planktonic species of Strombidium having an apparently weak chemical response to prey, with the efficient kinetic response in the benthic Strombidium sulcatum (Fenchel \& Jonsson 1988), By theoretical considerations, it is possible to further examine the potential of chemical gradients for vertical orientation in the pelagial. Assuming a kinetic response to a prey gradient, the time taken for a ciliate to move from one end of the gradient to the other can be calculated to be of the order of $1^{2} / D_{c}$, where $\mathrm{l}=$ length of the gradient; $\mathrm{D}_{\mathrm{c}}=$ motility (diffusion coefficient) of the ciliate (Okubo 1980, Fenchel 1987). If $D_{c}$ is about $1 \mathrm{~mm}^{2} \mathrm{~s}^{-1}$, which is typical of many ciliates, a vertical gradient of $1 \mathrm{~m}$ would take on average $10 \mathrm{~d}$ to swim through. Another possibility for ciliates to orient in a gradient is by sensing the change of concentration during a path length (the distance moved between tumbles) and suppress the tumbling rate when they are swimming up a favourable gradient. This so-called transient response is much more efficient than a simple kinetic response, provided that the gradient is sufficiently steep. As a rough example, I assume a ciliate like S. reticulatum swimming in a helix with a swimming speed of 1000 $\mu \mathrm{m} \mathrm{s}^{-1}$ (Table 4) yielding a transportation rate of 500 $\mu \mathrm{m} \mathrm{s}^{-1}$ and a tumbling frequency of $0.25 \mathrm{~s}^{-1}$ (Fig. 6b). If tumbling rate is suppressed to $0.15 \mathrm{~s}^{-1}$ when the ciliate covers $75 \%$ of the maximum upward gradient in one path length, a stochastic simulation shows that the vertical velocity would be about $150 \mu \mathrm{m} \mathrm{s}^{-1}$. This is not far from the vertical velocities actually found (Table 1 ). However, it is difficult to find gradients over several meters long which are sufficiently steep so that a ciliate may sense a change in one path length of some $\mathrm{mm}$. Chemosensory orientation in ciliates may be important on a microscale, e.g. when a predator approaches a prey, but it is probably safe to assume that it is not important in modest gradients over several meters.

\section{Geotaxis}

A possible cue to vertical orientation is of course gravity. Many protists are known to swim upwards or downwards in the absence of other stimuli. This has been described as geotaxis. True geotaxis mediated by a statocyst-like mechanoreceptor has recently been demonstrated for a limnic ciliate (Fenchel \& Finlay $1984,1986)$, but so far this is only known for the ciliate family Loxodidae. Roberts $(1970,1981)$ has explained other cases of apparent geotaxis as a result of sinking velocity and some asymmetry of the cell, either in density or hydrodynamical drag. When a cell which is denser then the medium sinks through the water an asymmetry in density will cause the centre of buoyancy a

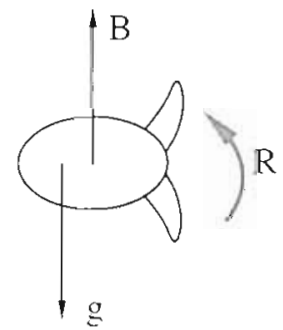

b

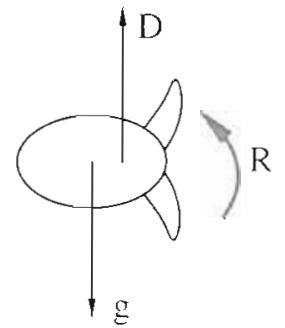

Fig. 11 Schematic drawing showing (a) separation of the centre of gravity, $g$, and the centre of buoyancy, $B$, and the induced torque, $\mathrm{R}$, due to density asymmetry and (b) separation of the centre of gravity and the centre of drag, D, due to shape asymmetry 
and the centre of gravity to be separated and a gravity induced torque will start to reorient the cell until the centres are aligned with the force of gravity (Fig. 11a). An asymmetry in shape, with accompanying asymmetry in hydrodynamical drag, will reorient the cell in an analogous way until the centre of gravity and the centre of drag align with the force of gravity (Fig. 11b). If there is a front-rear asymmetry, the cell will either swim downwards or upwards. It can also be shown that for cells reorienting with the anterior end upward, the vertical position is a balance between swimming velocity, sinking velocity, tumbling rate and reorientation rate (Roberts 1970). In summary, it can be concluded that although no gravity sensing organelle is present a ciliate may respond to gravity through interactions between sinking velocity and the morphology of the cell. The ciliate can not perceive the direction of gravity, so it is not a true taxis, and instead I will here refer to it as passive geotaxis.

In none of the planktonic ciliates studied have I found a mechanoreceptor that might function as a gravity sensor. Fenchel \& Finlay (1984) calculated that to overcome Brownian motion a statocyst must be at least a few microns and thus it should be visible in light microscopy. A mechanoreceptor must affect the activity of the cilia in order to mediate the direction of gravity to an appropriate behavioural response. Geotaxic correction of ciliates deviating from the desired orientation probably always involves repeated tumbling with small changes of direction as described in Fenchel \& Finlay (1984). No such tumbling behaviour was observed in this study, instead changes in vertical orientation of ciliates are smooth and continuous. The observations that changes in light intensity and temperature reverse the vertical distribution (Figs. 5 and 7 ) and that this correlates with changes in swimming behaviour, also suggest a labile, passive geotaxis rather than a mechanoreceptor-based true geotaxis.

The high reorientation rates found for fixed oligotrich ciliates (Table 3), and experiments with scale-models in glycerol, suggest that asymmetries in density and drag could be mechanisms causing planktonic oligotrich ciliates to swim upwards. They show a pronounced asymmetry in shape due to the oral membranelles and it seems reasonable to believe that the membranelles account for significant drag but contribute little to cell weight. This should reorient a cell with the anterior end upwards. Furthermore, the posterior 'cap' of polysaccharide cortical plates should also contribute to this reorientation by making the posterior end denser. Knowing the parameters of swimming behaviour, sinking velocity and reorientation rate, the expected vertical distribution can be analytically calculated (Roberts 1970) and compared to that actually found. If this is applied to the high reorientation rates found in this study, the distributions are expected to be much more skewed to the surface than actually found in the watercolumn experiments (Fig. 3). One explanation for this discrepancy is that the high reorientation rates, between 20 and $30^{\circ} \mathrm{s}^{-1}$, were obtained from measurements on fixed non-motile ciliates. In swimming ciliates, the reorientation component caused by the drag of the membranelles will only be effective when ciliates stop swimming, e.g. during tumbles. This is indicated by the low reorientation rate of living Lohmanniella oviformis, where reorientation is presumably caused by the membranelles when this ciliate 'hovers' between sudden jumps. Another important characteristic of real populations that makes the distribution broader, is the great variation in behaviour between individuals, e.g. between dividing and nondividing cells (Fig. 4). Unfortunately, it is difficult to formulate a model of vertical distribution that includes this individual variation of reorientation rates, sinking velocity and swimming behaviour

The experiment with manipulations of the density of Tintinnopsis campanula and its medium strongly suggests that the lorica of tintinnids has an effect on reorientation of the cell resulting in upward swimming. The use of deuteriumoxide (heavy water) first requires a cautionary remark. Deuteriumoxide is known to affect the physiology of cells in various ways e.g. the structure of microtubuli. The concentrations of deuteriumoxide I used in the experiments did not apparently alter swimming speed and tumbling rate but it can not be excluded that swimming behaviour might have been affected. However, the similar results of vertical velocity in seawater obtained before and immediately after the treatment with deuteriumoxide (Table 4) suggest that the differences in vertical velocity between seawater and the medium containing deuteriumoxide are not caused by any physiological change. From the experiments with $T$. campanula, I conclude that the lorica creates a density asymmetry in the tintinnid with the denser lorica inducing a torque tending to reorient the tintinnid with the lorica downwards. This would lead to the observed upward swimming and accumulation at the surface. Reducing this density asymmetry either by reducing weight of the lorica with latex beads or by increasing the buoyancy with a denser medium resulted in the expected reduction of vertical velocity. Although not statistically different, the trend of increased vertical velocity in seawater after swimming in the deuteriumoxide medium may be explained by assuming that the large space inside the lorica not occupied by the cell was initially filled with the deuteriumoxide mixture and the density asymmetry in the tintinnid was further accentuated.

There is a great diversity of lorica shapes and build- 


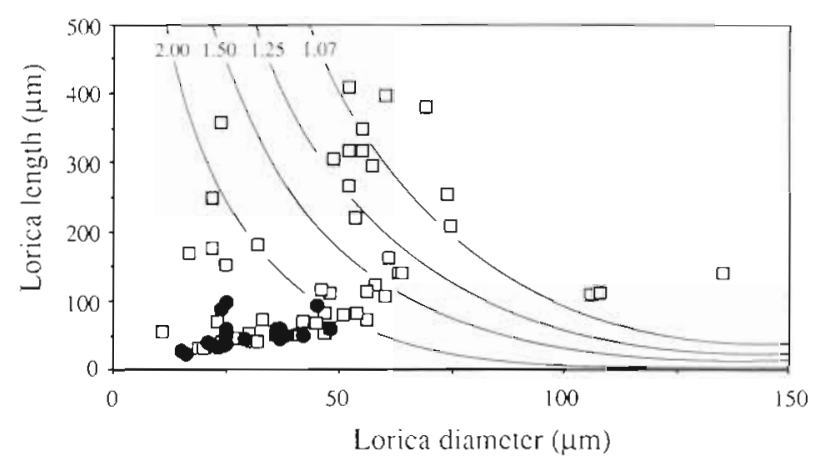

Fig. 12. Lorica size in agglutinated (filled circles) and hyaline tintinnids (open squares). Isolines show where tintinnid sinking velocity is $300 \mu \mathrm{m} \mathrm{s}^{-1}$ as a function of lorica size and density $\left(\mathrm{g} \mathrm{cm}^{-3}\right)$

ing materials among different species of tintinnids. Some species agglutinate mineral particles to the lorica and other species build a hyaline lorica entirely of organic substances. The vertical distribution of the hyaline Helicostomella subulata shows that the possession of a lorica with mineral particles is not necessary for upward swimming, but the experiments with Tintinnopsis campanula indicate that a lorica without mineral particles results in reduced vertical velocity. A lorica built of organic macro-molecules will still be denser than the cell and may cause reorientation. It may be speculated that when mineral particles are available a small agglutinated Iorica results in sufficient reorientation. In tropical and off-shore areas where mineral particles are scarce, large hyaline species often dominate. The construction of a large lorica of less dense organic material may be an alternative strategy to have a small, dense lorica to achieve reorientation. It is probably also important that species building large loricae possess some mechanism that prevents incorporation of mineral particles since sinking velocity will approach swimming velocity as the lorica becomes denser. This is illustrated in Fig. 12, where together with data gathered on lorica size (Marshall 1969, Capriulo \& Carpenter 1983, Verity 1987) for species with agglutinated and hyaline loricae, isolines for a sinking velocity of $300 \mathrm{\mu m} \mathrm{s}^{-1}$ are shown as a function of lorica size and lorica density. The calculations of sinking velocity assume a cylindrical shape of tintinnids, that the cell completely fills the lorica, a cell density of $1.07 \mathrm{~g} \mathrm{~cm}^{-3}$ and a Stokes radius. This roughly shows that agglutination of the lorica constrains the possible lorica size.

If many planktonic ciliates gain in fitness by directed swimming upwards, why have not special perception organelles evolved instead of the passive geotaxis suggested in this study? A statocyst-like mechanoreceptor would be the obvious choice but this kind of organelle is presently known only in the ciliate family Loxodidae
(Fenchel \& Finlay 1984, 1986). Another possibility would be an organelle sensitive to the direction of light, but phototaxis in ciliates has unambiguously only been described in Stentor coeruleus (Song et al. 1980). The lack of these perception organelles in tintinnids and oligotrichs may thus be due to phyletic constraints. However, a true physiological taxis may also be a disadvantage in the turbulent marine pelagial. Frequent changes of the cell orientation caused by water movements would trigger compensation responses to regain the upward orientation, including a series of tumbles. During tumbles, ciliary beat is reversed and feeding is interrupted, thus frequent disturbances would reduce time for feeding. A passive geotaxis can function constantly without interfering with feeding activities. The reduced precision may not be important in the marine pelagial where no steep gradients are normally found. In contrast, loxodid ciliates are living in low-turbulent environments where chemical gradients are very steep. A vertical difference of a few $\mathrm{mm}$ may be a matter of life and death and behavioural responses with high precision are necessary. Here the ability of loxodid ciliates to perceive gravity is clearly of great value.

\section{Ciliate movement and water turbulence}

The vertical velocities of some planktonic ciliates shown in Table 1 obviously enable ciliates to concentrate at the surface in experimental water-columns without any water turbulence, but will ciliate vertical velocities of 300 to $700 \mu \mathrm{m} \mathrm{s}{ }^{-1}$ be of any significance out in the turbulent pelagial? A strong biological indication that protists through motility may influence their vertical distribution comes from studies of diurnal vertical migrations of ciliates (Stoecker et al. 1984, McManus \& Fuhrman 1986) and dinoflagellates (e.g. Hasle 1950, Heaney \& Eppley 1981). Data are most extensive for migrating dinoflagellates which have vertical velocities similar to or lower (Heaney \& Eppley 1981) than found for the planktonic ciliates in this study, and their ability of diurnal changes in distribution patterns shows that swimming behaviour is not negligible compared to water movements.

The vertical turbulence of seawater is very difficult to measure directly, but if changes of salinity and temperature in space and time are known indirect estimates are possible. Such estimates of vertical eddy diffusivity, which measures turbulent transport, has been found to vary greatly between 0.04 and $100 \mathrm{~cm}^{2} \mathrm{~s}^{-1}$ depending on wind, waves, depth, currents and density stratification (Defant 1961). Sundby (1983) presented a model designed to describe the vertical distribution of pelagic fish eggs. The model considers the combined effect of 

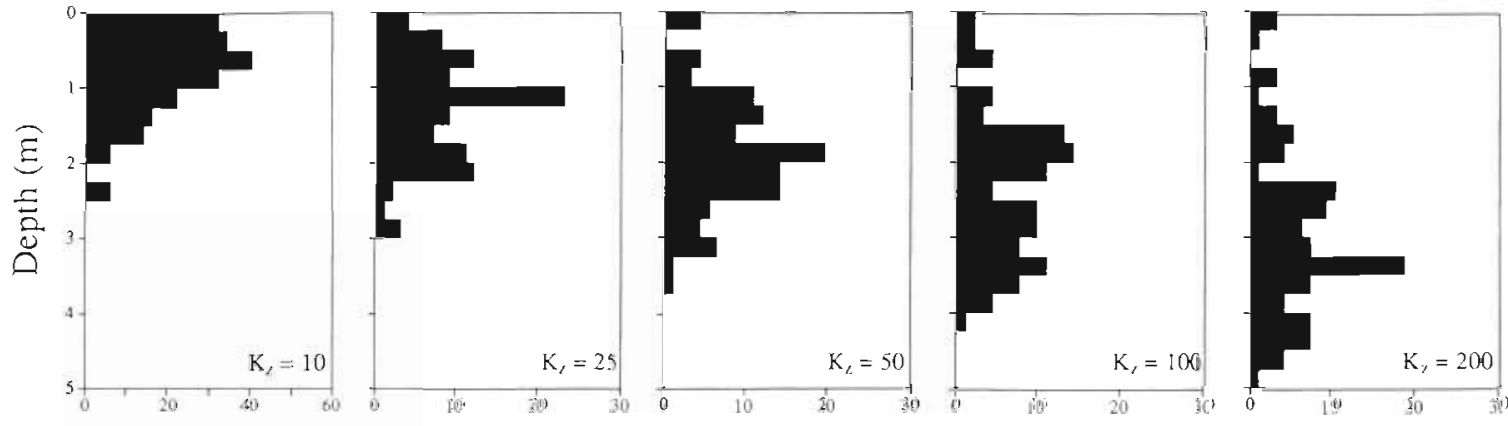

Abundance

Increasing turbulence rate

Fig. 13. Simulation of vertical distribution as a function of turbulent diffusion and vertical swimming velocity. Vertical diffusivity $\left(K_{z}\right)$ expressed as $\mathrm{cm}^{2} \mathrm{~s}^{-1}$ was varied holding vertical swimming velocity at $0.05 \mathrm{~cm} \mathrm{~s}^{-1}$ and the pycnocline at $2 \mathrm{~m}$

vertical turbulence and the vertical velocity of positively buoyant eggs. The solution to the diffusion equation is

$$
C(z)=C(a) e^{-w / K(z-a)}
$$

where $\mathrm{C}(\mathrm{z})=$ concentration of eggs as a function of depth $z ; C(a)=$ concentration of eggs at the depth $a_{;}$ $w=$ vertical velocity of eggs; $K=$ eddy diffusivity. If this model is applied to the vertical velocities found for some planktonic ciliates, a significant accumulation of ciliates at the surface results below an eddy diffusivity of around $25 \mathrm{~cm}^{2} \mathrm{~s}^{-1}$. This indicates that planktonic ciliates will be able to influence their vertical position at least under some conditions of weather and hydrography. Equation (1) assumes a completely mixed water mass where the eddy diffusivity is constant with depth. Presence of a pycnocline will reduce eddy diffusivity with increasing depth and this will influence the distribution of ciliates. In an attempt to simulate a stratified water mass, a simple stochastic model was constructed. The model considers a water-column with 2 layers separated by a pycnocline. Turbulence is simulated as a stochastic vertical movement where the vertical diffusivity $\left(K_{z}\right)$ decays exponentially with depth and is $10 \%$ of the surface value at the pycnocline. Ciliates in the water-column move upwards with a higher probability than downwards in each time unit. Simulated on a computer, this model produced the distribution patterns shown in Fig. 13. The combined effect of swimming behaviour and turbulence in this model yields qualitatively different distribution patterns as a function of the relative order of turbulence rate and ciliate vertical velocity. When turbulence is low relative to vertical swimming velocity ciliates accumulate at the surface but with increasing turbulence the distribution peak moves towards the pycnocline. At intermediate turbulence bimodal distributions occur with maxima at the surface and around the pycnocline. The dynamics of the model are rather similar to a distribution process with a kinetic response where motility (diffusion coefficient) differs between 2 environments. Accumulation occurs in the environment with the lowest motility and the steady-state distribution will be inversely proportional to the local motility (Okubo 1980). With low turbulence, the diffusion rate is similar above and below the pycnocline and the directed swimming results in accumulation at the surface. When turbulence increases, the diffusion rate of ciliates is higher above the pycnocline and ciliates accumulate below where motility is lower. Directed movement causes ciliates to concentrate around the pycnocline where the transition of diffusion rates occurs. This model tentatively explains why many of the ciliates studied in the field showed local maxima around the pycnocline and the often sudden reduction in abundance below the pycnocline (Fig, 1). In addition, it suggests that differences in distribution patterns among species may be a result of differences in swimming velocity.

\section{Ecological implications}

If many planktonic ciliates have the ability to swim upwards and to accumulate in surface waters, what are the ecological implications? A predator that can orient towards prey can grow at lower prey concentrations than a predator that moves randomly. Generally, suitable prey for ciliates are found in surface waters, and prey decrease in abundance with depth. Vertical swimming would therefore increase the probability that a ciliate would move into and remain in areas rich in prey, and thus the ingestion rate of prey should be higher than if the ciliates movement were random. This also bears on sampling strategy, where heterogeneous distributions of ciliates may result in erroneous estimates of average abundance, reproduction and cal- 
culated ingestion rates. The difference in distribution of non-dividing and dividing cells (Fig. 4) also calls for some caution when the frequency of dividing cells (Hagström et al. 1979, Coats \& Heinbokel 1982) is used as a measure of in situ reproduction rate.

It may be speculated that differences in mean vertical velocity will separate different species vertically, thus reducing competition. The lability of the suggested passive geotaxis as indicated in Figs. 5 to 7 could also alter vertical distributions of planktonic ciliates as a result of changes in water temperature and availability of mineral particles for tintinnids. This could affect the distributions of species differently according to their responses to changes in the environment. A species adapted to warm water may lose the ability to swim upwards in cold water if swimming speed is reduced. Similarly, vertical distributions of tintinnid species may or may not be affected by availability of inorganic particles depending on the type of lorica. If the vertical position in the water-column influences survival and reproduction rates, some species may therefore be excluded from the pelagial under some conditions. Upward swimming could also increase fitness in species with life-cycles in which encystment occurs (Paranjape 1980, Reid 1987). Ciliates excysting from cysts settled on the bottom would be guided towards the surface by directed swimming.

Passive geotaxis is an example of how behaviour is affected by the morphology of the organism. Morphology is of course largely a result of physiological processes during ontogeny, but the behaviour is termed passive because the reorientation rate of the individual ciliate may be viewed as a fixed trait determined by morphology. It is important to point out that even if this reorientation is a passive consequence of morphology it may still be an adaptation. If individuals gain in fitness by upward swimming, due to certain heritable features of morphology, this will lead to evolution of reorientation by natural selection. This also implies that if passive geotaxis increases fitness of ciliates inhabiting the pelagial, only a limited set of cell morphologies may be expected. Many unrelated planktonic ciliates such as species of Urotricha, Cyclotrichium, Mesodinium, Tiarina and the Oligotrichida share the possession of long oral cilia or membranelles arranged in a peristomial ring. It may be speculated that this convergence of morphology is partly the result of selection for an increased upward reorientation of the cell.

Finally, I suggest that passive geotaxis, based on density asymmetry, may also apply to some planktonic rotifers (e.g. genus Keratella) and several planktonic larvae of benthic invertebrates, e.g. molluscan veliger larvae.
Acknowledgements. I am grateful to Professor Anders Stigebrandt for valuable discussions about turbulent water trans. port. I also thank one anonymous referee who greatly improved the readability of the manuscript. This study was supported by the Swedish Natural Science Research Council through contract B-DT 1860-107

\section{LITERATURE CITED}

Andersen, P., Sorensen, H. M. (1986). Population dynamics and trophic coupling in pelagic microorganisms in eutrophic coastal waters. Mar. Ecol. Prog. Ser. 33: 99-109

Azam, F., Ammerman, J. W. (1984). Cycling of organic matter by bacterioplankton in pelagic marine ecosystems: microenvironmental considerations. In: Fasham, M. J. R. (ed.) Flows of energy and materials in marine ecosystems Plenum Press, New York, p. 345-360

Azam, F., Fenchel, T., Field, J. G., Gray, J. S., Meyer-Reil, L. A., Thingstad, F. (1983). The ecological role of watercolumn microbes in the sea. Mar. Ecol. Prog. Ser 10 $257-263$

Bakker, C.. Phaff, W. J. (1976). Tintinnida from coastal waters of the S. W.-Netherlands I. The genus Tintinnopsis Stein. Hydrobiologia 50: 101-111

Beers, J. R., Stewart, G. L. (1969). The vertical distribution of microzooplankton and some ecological observations. J. Cons. int. Explor. Mer 33: 30-44

Capriulo, G. M. (1982). Feeding of field collected tintinnid micro-zooplankton on natural food. Mar. Biol. 71: 73-86

Capriulo, G. M., Carpenter, E. J. (1983). Abundance, species composition and feeding impact of tintinnid micro-zooplankton in central Long Island Sound. Mar. Ecol. Prog. Ser 10: $277-288$

Coats, D. W., Heinbokel, J. F. (1982). A study of reproduction and other life cycle phenomena in planktonic protists using an acridine orange fluorescence technique. Mar Biol. 67: $71-79$

Cox, R. A., McCartney, M. J, Culkin, F. (1970). The specific gravity/saline/temperature relationship in natural sea water Deep Sea Res. 17: 679-689

Defant, A. (1961). Physical Oceanography, Vol. I. Pergamon Press, Oxford

Eppley, R. W., Holm-Hansen, O., Strickland, J. D. H. (1968) Some observations on the vertical migration of dinoflagellates. J. Phycol. 4: 333-340

Fenchel, T. (1982). Ecology of heterotrophic microflagellates. IV Quantitative occurrence and importance as bacterial consumers. Mar Ecol. Prog Ser. 9: 35-42

Fenchel, T (1987). Ecology of Protozod. Science Tech/ Springer Verlag, Madison

Fenchel, T., Finlay, B. J. (1984). Geotaxis in the ciliated protozoon Loxodes. J. exp. Biol. 110: 17-33

Fenchel, T., Finlay, B. J. (1986). The structure and function of Müller vesicles in Loxodic ciliates. J. Protozool. 33: 69-76

Fenchel, T., Jonsson, P. R. (1988). The functional biology of Strombidium sulcatum, a marine oligotrich ciliate (Ciliophora, Oligotrichina). Mar Ecol. Prog. Ser. 48: 1-15

Finlay, B. J., Berninger, U.-G., Stewart, J. L., Hindle, R. M., Davison, W. (1987). Some factors controlling the distribution of two pond-dwelling ciliates with algal symbionts (Frontonia vernalis and Euplotes daidaleos). J. Protozool. 34: 349-356

Gillbricht, M. (1955). Wucherungen von Phytoplankton in einem abgeschlossenen Hafenbecken. Helgoländer wiss. Meeresunters. 5: 141-168 
Hagström, A., Larsson, U., Hörstedt, P., Normark, S. (1979). Frequency of dividing cells, a new approach to the determination of bacterial growth rates in aquatic environments. Appl. environ. Microbiol. $37 \cdot 805-812$

Hasle, G. R. (1950). Phototactic vertical migration in marine dinoflagellates. Oikos 2: 162-175

Heaney, S. I., Eppley, R. W (1981). Light, temperature and nitrogen as interacting factors affecting diel vertical migrations of dinoflagellates in culture. J. Plankton Res. 3: $331-344$

Heinbokel, J. F. (1978). Studies on the functional role of tintinnids in the Southern California Bight. II. Grazing rates of field populations. Mar Biol 47: 191-197

Jonsson, P. R. (1986). Particle size selection, feeding rates and growth dynamics of marine planktonic oligotrichous ciliates (Ciliophora: Oligotrichina). Mar. Ecol. Prog. Ser 33: $265-277$

Laval-Peuto, M., Brownlee, D. C. (1986). Identification and systematics of the Tintinnina (Ciliophora): evaluation and suggestions for improvement. Annls Inst. océanogr., Paris 62: $69-84$

Leegaard. C. (1915). Untersuchungen über einige Planktonciliaten des Meeres. Nytt Mag. Naturvid. 53: 1-37

Longhurst, A. R. (1976). Vertical migration. In: Cushing, D. H., Walsh, J. J. (eds.) The ecology of the seas. Blackwell, Oxford, p. 116-137

Marshall, S. M. (1969). Protozoa order- Tintinnida. Cons. int. Explor. Mer, Zooplankton Sheets No. 117-127

Marshall, S. M., Orr, A. P. (1955). The biology of a marine copepod Calanus finmarchicus (Gunnerus). Oliver and Boyd, Edinburgh

McManus, G. B., Fuhrman, J. A. (1986). Photosynthetic pigments in the ciliate Laboea strobila from Long Island Sound, USA. J. Plankton Res. 8: 317-327

Middlebrook, K., Emerson, C. W., Roff, J. C., Lynn, D. H. (1987). Distribution and abundance of tintinnids in the Quoddy Region of the Bay of Fundy. Can. J. Zool. 65: $594-601$

Okubo, A. (1980). Diffusion and ecological problems: mathematical models. Springer-Verlag, Berlin

Paranjape, M. A. (1980). Occurrence and significance of rest-

This article was submitted to the editor ing cysts in a hyaline tintinnid, Helicostomella subulata (Ehre.) Jorgensen. J. exp. mar Biol. Ecol. 48: 23-33

Rassoulzadegan, F. (1982). Dependence of grazing rate, gross growth efficiency and food size range on temperature in a pelagic oligotrichous ciliate Lohmanniella spiralis Leeg., fed on naturally occurring particulate matter Annls Inst. océanogr., Paris 58: 177-184

Rassoulzadegan, F., Etienne, M. (1981). Grazing rate of the tintinnid Stenosemella ventricosa (Clap. \& Lachm.) Jörg. on the spectrum of the naturally occurring particulate matter from a Mediterranean neritic area. Limnol. Oceanogr 26: 258-270

Reid, P. C. (1987). Mass encystment of a planktonic oligotrich ciliate. Mar Biol. 95: 221-230

Roberts, A. M. (1970). Geotaxis in motile micro-organisms. J. exp. Biol. 53: 687-699

Roberts, A. M. (1981). Hydrodynamics of protozoan swimming. In: Levandowsky, M., Hutner, S. H. (eds.) Biochemistry and physiology of protozoa, Vol.4. Academic Press, New York, p. 5-66

Sherr, E., Sherr, B. (1987). High rates of consumption of bacteria by pelagic ciliates. Nature, Lond. 325: 710-711

Song, P. S., Häder, D.-P., Poff, K. L. (1980). Phototactic orientation by the ciliate Stentor coeruleus. Photochem. Photobiol 32: $781-786$

Spittler, P. (1973). Feeding experiments with tintinnids. Oikos 15 (Suppl.): 128-132

Stoecker, D. K., Davis, L. H., Anderson, D. M. (1984). Fine scale spatial correlations between planktonic ciliates and dinoflagellates. J. Plankton Res. 6: 829-842

Sundby, S. (1983). A one-dimensional model for the vertical distribution of pelagic fish eggs in the mixed layer Deep Sea Res. 30: 645-661

Verity, P. G. (1986). Grazing of phototrophic nanoplankton by microzooplankton in Narragansett Bay. Mar Ecol. Prog. Ser. 29: 105-115

Verity, P. G. (1987). Abundance, community composition, size distribution, and production rates of tintinnids in Narragansett Bay, Rhode Island. Estuar. coast. Shelf Sci. 24: 671-691

Vitiello, P. (1964). Contribution à l'étude des Tintinnides de la baie d'Alger. Pelagos 2: 5-42

Manuscript received: July 27, 1988

Revised version accepted: November 2, 1988 